УДК 330.14.001.82-047.44(045)

DOI: https://doi.org/10.37320/2415-3583/12.3

Максименко Ж.В.

аспірантка,

Національний авіаційний університет

\title{
СТРУКТУРНИЙ ПІДХІД МЕТОДИКИ ОЦІНЮВАННЯ ІНТЕЛЕКТУАЛЬНОГО КАПІТАЛУ НАЦІОНАЛЬНОЇ ЕКОНОМІКИ
}

У статті розглянуто парадигму оцінювання інтелектуального капіталу. Досліджено гносеологію інтелектуального капіталу. Систематизовано дослідницькі підходи науковців до структурних компонентів інтелектуального капіталу. Обгрунтовано систему показників структурного підходу до оцінювання інтелектуального капіталу. Узагальнено структурні компоненти та методологію оцінювання інтелектуального капіталу на державному рівні управління. Розглянуто формування інтелектуального капіталу на різних рівнях людського розвитку. Досліджено готовність національної економіки на основі Індексу економіки знань до інноваційної моделі розвитку. Обтрунтовано значення основних структурних компонентів програми «Знання задля розвитку». Автором запропоновано алгоритм методики SC-оцінювання інтелектуального капіталу за структурного підходу.

Ключові слова: інтелектуальний капітал, людський капітал, організаційний капітал, соціальний капітал, методика оцінювання.

Постановка проблеми. Світова наукова спільнота під час оцінювання вартості інтелектуального капіталу України надає вагомого значення факторам формування та розвитку, структурним компонентам інтелектуального капіталу. Результати інтелектуальної праці покращують імідж країни на міжнародному ринку, забезпечують стабільність та розвиток національної економіки. Актуальність теми зумовлена неузгодженістю серед позицій науковців щодо структурних компонентів та методики оцінювання інтелектуального капіталу під час дослідження явища капіталізації інтелектуального продукту.

Аналіз останніх досліджень і публікацій. Дослідженням проблем визначення структури та методології оцінювання інтелектуального капіталу займалися вітчизняні науковці, такі як В. Бугас, І. Каленюк, О. Кендюхов, О. Комліченко, Н. Ротань, А. Чухно, та зарубіжні вчені, такі як Г. Беккер, Е. Брукінг, С. Дятлов, Л. Едвісон, В. Зінов, Р. Каплан, В. Мар'яненко, М. Мелоун, Д. Нортон, О. Прокопенко, Г. Река, К. Сафа- 
рян, Т. Селищева, С. Смірнов, Р. Старик, Г. Ступнікер, Т. Стюарт, В. Школа, Т. Шульц, В. Щербаченко. 3 огляду на диференційованість наукових праць проблема визначення структурних компонентів та єдиної ефективної методики оцінювання інтелектуального капіталу для національної економіки залишається актуальною.

Мета статті полягає у визначенні за структурного підходу методології оцінювання інтелектуального капіталу національної економіки.

Виклад основного матеріалу. Гносеологія інтелектуального капіталу (IК) грунтується на основі людського капіталу, заснованого Т. Шульцом. Науковець досліджував людський капітал на макрорівні, обгрунтовував важливість інвестування в освіту [1]. Иого дослідження на мікрорівні продовжив Г. Беккер. Згідно з Г. Беккером, людський капітал визначається як знання, кваліфікація, навички та вміння працівників компанії. Г. Беккер проаналізував прямі та непрямі витрати на навчання, втрачений дохід за період навчання, а також встановив співвідношення між доходами та витратами на освіту у розмірі 14\% [2].

За даними досліджень більшість міжнародних та вітчизняних науковців виокремлює такі три складові частини IК (табл. 1):

- людський капітал;

- структурний капітал;

- споживчий або клієнтський капітал.

Таблиця 1 - Дослідницькі підходи до структури інтелектуального капіталу

\begin{tabular}{|c|c|}
\hline Науковці & $\begin{array}{c}\text { Складові частини } \\
\text { інтелектуального капіталу }\end{array}$ \\
\hline $\begin{array}{l}\text { I. Каленюк } \\
{[3, \text { с. 4-13] }}\end{array}$ & $\begin{array}{l}\text { 1) Людський капітал; } \\
\text { 2) структурний капітал; } \\
\text { 3) споживчий або клієнтський } \\
\text { ринковий капітал. }\end{array}$ \\
\hline Т. Стюарт [4] & $\begin{array}{l}\text { 1) Людський капітал; } \\
\text { 2) структурний капітал; } \\
\text { 3) споживчий (клієнтський) капітал. }\end{array}$ \\
\hline Е. Брукінг[5] & $\begin{array}{l}\text { 1) Ринкові активи; } \\
\text { 2) інтелектуальна власність; } \\
\text { 3) людські активи; } \\
\text { 4) інфраструктурні активи. }\end{array}$ \\
\hline В. Бугас [6] & $\begin{array}{l}\text { 1) Людський капітал; } \\
\text { 2) організаційний капітал; } \\
\text { 3) клієнтський капітал. }\end{array}$ \\
\hline О. Кендюхов [7] & $\begin{array}{l}\text { 1) Персоніфікований; } \\
\text { 2) інфраструктурний; } \\
\text { 3) кліснтський; } \\
\text { 4) марочний; } \\
\text { 5) формалізована інтелектуальна } \\
\text { власність. }\end{array}$ \\
\hline $\begin{array}{l}\text { Л. Едвісон, } \\
\text { М. Мелоун [8] }\end{array}$ & $\begin{array}{l}\text { 1) Людський капітал; } \\
\text { 2) структурний капітал. }\end{array}$ \\
\hline А. Чухно $[9$, с. 61-67] & $\begin{array}{l}\text { 1) Людський; } \\
\text { 2) технологічний. }\end{array}$ \\
\hline $\begin{array}{l}\text { В. Зінов, К. Сафарян } \\
{[10, \text { с. } 23-25]}\end{array}$ & $\begin{array}{l}\text { 1) Людський капітал; } \\
\text { 2) інтелектуальні ресурси. }\end{array}$ \\
\hline
\end{tabular}

Джерело: складено автором

Вчені по-різному трактують структуру та значення IK, адже, крім людського, варто виокремити організаційний (структурний) та клієнтський (споживчий) капітал. Організаційний капітал становить організаційну структуру та систему управління бізнесом (бази даних, комунікаційні та електронні мережі). Клієнтський капітал пов'язують з репутацією фірми, адже він передбачає торгові марки, зв'язки з клієнтами, що встановлюються на довірі. Нині важливою $€$ ефективність оцінювання вартості ІК. На рівні підприємства виокремлюють більше 40 методів оцінювання вартості IК.

Парадигма оцінювання IК має три складові частини, такі як підходи, методи, методика. Підходи визначають принципи оцінювання вартості IK, методи - процедуру розрахунку вартості, а методика застосування методу щодо об'єктів інтелектуальної власності та цілей розрахунку.

Згідно з К. Свейбі, методика оцінювання IK об'єднана в такі чотири групи [11]:

- методи прямої грошової оцінки окремих складових частин IK (DIC);

- методи ринкової капіталізації (МCM), що оцінюють різницю між ринковою і балансовою вартістю активів підприємства;

- методи рентабельності активів (ROA), що оцінюють різницю між середньогалузевою рентабельністю активів і рентабельністю підприємства, тобто додаткову ефективність, яку генерує IК;

- методи збалансованих показників (SC), за яких розраховуються індекси та індикатори, що характеризують відповідні елементи ІК.

В економіці виділяють три підходи методів прямої грошової оцінки вартості ІК, такі як витратний, порівняльний (ринковий), дохідний.

Витратний підхід - це підхід, за якого покупець контролює витрати на створення продукту. Вартість об'єкта складається з витрат на його створення та введення в дію. Він є невигідним для продавця, оскільки не приносить прибутку.

Порівняльний підхід, або ринковий, характеризується оцінкою продажів 3 іншими аналогічними об'єктами. Ціна встановлюється ринком відповідно до якості та корисності об'єкта й влаштовує як покупця, так і продавця.

Дохідний підхід грунтується на інвестуванні коштів в об'єкт інтелектуальної власності задля отримання доходу.

Вартість IК - це різниця між балансовою та ринковою вартістю. Особливістю цих методів $є$ визначення вкладу інтелектуального капіталу задля підвищення вартості бізнесу.

Головною функцією ІК є отримання додаткової вартості (доходу). Отже, сьогодні вагомого значення набуває діяльність стейкхолдерів, які забезпечують проходження життєвого циклу матеріального та нематеріального товару. Стейкхолдер - це фізична, юридична особа чи група осіб, зацікавлених у виробництві продукції (виробники, замовники, постачальники).

Методи оцінювання IК Р. Старик [12, с. 233-241], О. Прокопенко [13, с. 31-36], С. Смірнов [14, с. 219-224], Г. Ступнікер [15, с. 40-43], Г. Река [16, с. 240-246] класифікують за рівнями дослідження (державний, регіональний, підприємницький); підходами до оцінювання (витратні, дохідні, експертні); аналоговими методами (порівняння продажів та інтелектуальної власності). 
Парадигма оцінювання IК на макрорівні є дещо складнішою, ніж на підприємстві, оскільки ми не можемо порахувати пряму грошову вартість національного інтелектуального продукту. Для регіонального або державного рівня актуальним буде застосування індексних, індикаторних (Scorecard Methods) та експертних методів оцінювання. Також визначають вагомість впливу структурних компонентів на інтелектуальний капітал за допомогою математичних моделей, гармонійної, середньої зваженої, багатовимірної середньої або ЕОМ (наприклад, програма "Statistica").

У 90-х роках XX століття ефективною стала методологія оцінювання IК методом системи збалансованих показників (Balanced Scorecard), розроблена у США Р. Капланом і Д. Нортоном. Оскільки компанії досить велику увагу приділяли фінансовим показникам, було виявлено, що задля покращення короткострокових фінансових результатів здійснювалося зниження витрат на навчання, маркетинг та обслуговування клієнтів, а це в подальшому негативно позначилось на фінансовому стані організацій [17].

Згідно з Balanced Scorecard [17] стратегія бізнес-компанії складається 3 чотирьох перспектив, таких як фінансова, клієнтська, перспектива процесів навчання й зростання. За С. Дятловим, Т. Селищевою, В. Мар'яненком [18], методи збалансованих показників (Scorecard Methods) - це негрошові методи оцінки IK за допомогою підрахунку балів на основі індексів та індикаторів показників структурних компонентів IK. Scorecard Methods включає такі методи, як метод Д. Петерсона та Т. Паркінсона, метод Дж. Тобіна, метод П. Страсмана, метод NCI Research, метод А. Пуліка.

Розглянемо деякі з них [18].

1)Метод П. Страсмана передбачає визначення вартості ІК на основі інформаційного менеджменту (за допомогою активів, інвестицій, акціонерного капіталу). Оцінювання менеджменту грунтується на визначенні частки доходу університету, яка припадає на ефективність управління, також за цього методу визначають ефективність діяльності деканатів.

2)Метод А. Пуліка передбачає визначення IК на основі доданої вартості від ІК (визначається вартість структурного та людського капіталу).
3) Метод NCI Research передбачає, що вартість IK визначається на основі показників ефективності бізнесу.

Найбільш поширеними структурними підходами до оцінювання IК на національному рівні є оцінювання за міжнародними рейтингами; оцінювання за освітніми системами; оцінювання інноваційної діяльності.

За нашими дослідженнями методика оцінювання IK на макрорівні грунтується на визначенні ефективності формування інтелектуального капіталу; визначенні результатів використання інтелектуального капіталу (впровадження інноваційної продукції).

Автором узагальнено показники для оцінювання IK за структурного підходу за допомогою табл. 2.

Отже, формування та розвиток інтелектуального капіталу відбуваються на трьох рівнях, а саме індивідуальному (особистісному), на рівні підприємства (мікрорівень), на рівні держави (макрорівень).

Індивідуальний розвиток - це розвиток, на який впливають сім'я, суспільство, засоби масової інформації, освітні заклади. Завданнями держави для досягнення високого інтелектуального (людського) розвитку $€$ формування морально-етичних норм, збереження культурних традицій, фінансова допомога для малозабезпечених та багатодітних сімей (субсидії, соціальні виплати), фінансування наукових (творчих) проєктів обдарованої молоді. На цьому рівні ми можемо сформувати та розвивати соціальний капітал, довіру громадян до органів державної або місцевої влади, навчальних закладів, надаючи можливості вибору навчального закладу (навчання за держбюджетом, міжнародні наукові гранди та стипендії), гідну оплату праці, відчуття безпеки в країні, соціальну підтримку.

На рівні підприємства на формування інтелектуального капіталу впливає професійна освіта співробітників, індивідуальні знання, можливість підвищення кваліфікаційних навичок (людський капітал), наявність потенціалу до виробництва інноваційного продукту, менеджмент управління (організаційний капітал) та клієнтські зв'язки, імідж компанії тощо.

На макрорівні варто замінити клієнтський капітал соціальним, оскільки, крім фінансової підтримки розвитку освіти та науки, завданнями держави є встанов-

Таблиця 2 - Показники для оцінювання інтелектуального капіталу за його структурними елементами

\begin{tabular}{|c|c|c|c|}
\hline $\begin{array}{c}\text { Структурні компоненти } \\
\text { інтелектуального } \\
\text { капіталу }\end{array}$ & $\begin{array}{c}\text { Оцінка за міжнародними } \\
\text { рейтингами }\end{array}$ & $\begin{array}{c}\text { Оцінка за освітніми } \\
\text { системами }\end{array}$ & $\begin{array}{c}\text { Оцінка у промисловій } \\
\text { сфері }\end{array}$ \\
\hline Людський капітал & $\begin{array}{l}\text { - Індекс людського розвитку; } \\
\text { - Глобальний інноваційний індекс; } \\
\text { - Глобальний індекс } \\
\text { конкурентоспроможності талантів. }\end{array}$ & $\begin{array}{l}- \text { Кількість випускників } \\
\text { усіх рівнів здобутої освіти; } \\
- \text { державні та приватні } \\
\text { інвестиції в освіту. } \\
\end{array}$ & $\begin{array}{l}\text { - Кількість працівників, що } \\
\text { підвищили кваліфікацію; } \\
-\quad \text { кількість працівників із } \\
\text { академічною освітою. }\end{array}$ \\
\hline $\begin{array}{l}\text { Клієнтський капітал } \\
\text { (споживчий) або } \\
\text { соціальний капітал. }\end{array}$ & $\begin{array}{l}\text { - Глобальний індекс } \\
\text { конкурентоспроможності; } \\
-\quad \text { Індекс інноваційної привабливості. }\end{array}$ & $\begin{array}{l}\text { Довіра між викладачами та } \\
\text { студентами. }\end{array}$ & $\begin{array}{l}\text { Реалізована інноваційна } \\
\text { продукція. }\end{array}$ \\
\hline $\begin{array}{l}\text { Структурний капітал } \\
\text { (організаційний) }\end{array}$ & $\begin{array}{l}\text { - Глобальний індекс } \\
\text { конкурентоспроможності; } \\
\text { - Свропейське інноваційне табло; } \\
\text { - «Інноваційний індекс»; } \\
\text { - Глобальний інноваційний індекс } \\
\text { “Вloomberg”: патентна активність; } \\
\text { - рейтинг ведення бізнесу. }\end{array}$ & $\begin{array}{l}\text { - Структура науковців за } \\
\text { віком, академічною освітою, } \\
\text { гендерною ознакою, } \\
\text { галузевою ознакою; } \\
- \text { наявність науково- } \\
\text { технічних та } \\
\text { інформаційних засобів. }\end{array}$ & $\begin{array}{l}\text { - Виконані наукові й } \\
\text { науково-дослідні роботи; } \\
\text { - кількість підприємств, } \\
\text { що займаються науково- } \\
\text { технічною діяльністю; } \\
\text { - підприємства, що } \\
\text { впроваджують інновації. }\end{array}$ \\
\hline
\end{tabular}

Джерело: складено автором 
лення соціальних зв’язків між громадянами країни та органами державного управління, прозорість та відкритість державного апарату, подолання корупції.

Проаналізувавши вищенаведені дані, можемо виділити структурні компоненти інтелектуального капіталу на макрорівні (рис. 1).

Погляди на формування структурних компонентів та оцінювання ІК змінюються разом із розвитком суспільства. 3'являються нові підходи, які більш грунтовно розкривають зміст та структуру ІК. Однак усі дослідження обгрунтовані єдиним змістом: ІК складається з різних капіталів, які уособлені в співробітниках, організаційній структурі, інтелектуальній власності та соціальних зв'язках.

За даними Програми розвитку ООН для оцінювання людського розвитку варто застосовувати індекс розвитку інтелектуального потенціалу, який складається 3 п’яти таких показників, як середня тривалість навчання зайнятого населення (індикатор досягнутої освіти); повнота охоплення початковою, середньою та вищою освітою (поточний індикатор освіти, пов'язаний з інвестиціями в освіту); кількість аспірантів у розрахунку на 100 тис. зайнятих (індикатор цільової підготовки наукових кадрів); кількість зайнятих дослідженнями та розробками в розрахунку на 100 тис. зайнятих (індикатор масштабів зайнятості науковими дослідженнями); частка внутрішніх витрат на дослідження та розробки у відсотках від ВВП (індикатор продуктивності наукових досліджень) [19].

Європейський банк реконструкцій та розвитку (СБРР) запропонував програму «Знання задля розвитку» ("Knowledge for Development", K4D). Методика дає змогу оцінити готовність країни до переходу на інноваційну модель розвитку. Програма K4D пропонує комплекс із 80 показників, які дають змогу порівнювати окремі показники різних країн, а також середні показники, що характеризують групу країн, а саме інституційний режим, ступінь освіти населення, інформаційно-комунікаційні технології, національна інноваційна система [20].

"Knowledge

Development"

for

\begin{tabular}{|l|}
\hline \\
\hline Людський капітал \\
\hline - Рівень грамотності \\
в країні; \\
- рівень охорони \\
здоров'я; \\
- фінансування \\
системи освіти та \\
науки; \\
- підвищення \\
кваліфікації \\
працівників. \\
\end{tabular}

зведені індекси, а саме Індекс економіки знань та Індекс знань. Індекс економіки знань (Knowledge Economy Index, KEI) - це середній із чотирьох індексів, а саме індексу інституційного режиму, індексу освіти, індексу інновацій та індексу інформаційних технологій і комунікацій. Індекс знань (Knowledge Economy, KE) це середня величина лише трьох 3 них, а саме індексу освіти, індексу інновацій та індексу інформаційних технологій і комунікацій [20].

Проаналізуємо індекс "Knowledge for Development" у табл. 3 .

Аналіз “Knowledge for Development” доводить, що інноваційно-інтелектуальний розвиток $є$ основним показником суспільного розвитку. Однак, згідно 3 Національною методикою оцінки регіонального людського розвитку [21], Україні варто перейти від оцінки рейтингів до оцінки прогресу національної економіки.

Розглянемо готовність національної економіки до інноваційної моделі розвитку за табл. 4.

Основними перешкодами інноваційного розвитку української економіки є слабкі інституції інновацій та відсутність інноваційної системи. Згідно 3 даними СБРР негативний вплив на індекс економіки знань мають неефективне управління та слабке бізнес-середовище, високий рівень сприйняття корупції в Україні.

Отже, формування та оцінювання інтелектуального капіталу базуються на трансформаційних процесах перетворення інтелектуального потенціалу людських ресурсів на інтелектуальний капітал.

\section{ІНТЕЛЕКТУАЛЬНИЙ КАПІТАЛ}

\begin{tabular}{|c|c|}
\hline Організаційний капітал & Соціальний капітал \\
\hline $\begin{array}{l}\text { - Об'єкти } \\
\text { інтелектуальної } \\
\text { власності (ноу-хау, } \\
\text { промислове та авторське } \\
\text { право); } \\
\text { - організація ведення } \\
\text { бізнесу; } \\
\text { - інформаційні } \\
\text { технологіі; } \\
\text { - електронні мережі. }\end{array}$ & $\begin{array}{l}\text { - Міжнародний рейтинг } \\
\text { країни; } \\
\text { - вступ України в } \\
\text { міжнародні організації (ООН); } \\
\text { - укладення Україною } \\
\text { міжнародних договорів; } \\
\text { - наукова співпраця із } \\
\text { закордонними колегами; } \\
\text { - соціальна допомога } \\
\text { населенню; } \\
\text { - забезпечення гідних умов } \\
\text { життя та праці в країні. }\end{array}$ \\
\hline
\end{tabular}

Таблиця 3 - Значення основних структурних компонентів "Knowledge for Development"

\begin{tabular}{|l|l|}
\hline \multicolumn{1}{|c|}{ Показник } & \multicolumn{1}{c|}{ Значення } \\
\hline Global Innovation Index & $\begin{array}{l}\text { Забезпечує комплексний погляд на інновації, але не охоплює всі світові економіки, в які } \\
\text { інвестує ЄБРР. }\end{array}$ \\
\hline Global Competitiveness Index & $\begin{array}{l}\text { Не зосереджується на рушіях інновацій, більше орієнтується на значення показників для } \\
\text { продуктивності. }\end{array}$ \\
\hline European Innovation Scoreboard & Є відповідним заходом інновацій, але він охоплює лише європейські економіки. \\
\hline Economic Complexity Index & $\begin{array}{l}\text { Орієнтований на додану вартість у продажах товарів, необ'єктивне сприйняття здатності } \\
\text { економіки до додавання вартості. }\end{array}$ \\
\hline Trade in value added & $\begin{array}{l}\text { База даних вимірює вартісні потоки галузевого виробництва товарів та послуг, вказуючи } \\
\text { на глобальні зв’язки ланцюга вартості між країнами. }\end{array}$ \\
\hline
\end{tabular}

Джерело: складено за даними СБРР [20] 
Таблиця 4 - Індекс економіки знань СБРР за 2018 рік

\begin{tabular}{|c|c|c|c|c|c|c|c|}
\hline № & Країна & $\begin{array}{c}\text { Загальна } \\
\text { оцінка (iз 10) } \\
\end{array}$ & $\begin{array}{r}\text { Рейтинг серед } \\
\text { економік СБРР }\end{array}$ & $\begin{array}{l}\text { Інституції } \\
\text { інновацій }\end{array}$ & $\begin{array}{c}\text { Навички } \\
\text { для інновацій } \\
\end{array}$ & $\begin{array}{c}\text { Інноваційна } \\
\text { система }\end{array}$ & $\begin{array}{c}\text { Iнформаційна } \\
\text { інфраструктура }\end{array}$ \\
\hline 1 & Естонія & 6,82 & 1 & 8,01 & 6,70 & 4,58 & 7,99 \\
\hline 2 & Словенія & 6,65 & 2 & 7,40 & 7,32 & 5,14 & 6,73 \\
\hline 3 & Литва & 6,03 & 3 & 7,24 & 5,85 & 4,04 & 6,97 \\
\hline 4 & Латвія & 5,88 & 4 & 7,36 & 6,31 & 3,04 & 6,80 \\
\hline 5 & Польща & 5,63 & 6 & 6,80 & 6,31 & 3,82 & 5,58 \\
\hline 6 & Білорусь & 5,21 & 11 & 5,50 & 6,05 & 3,27 & 6,01 \\
\hline 7 & Казахстан & 4,85 & 18 & 5,80 & 5,68 & 2,69 & 5,23 \\
\hline 8 & Монголія & 4,48 & 23 & 5,11 & 5,10 & 2,65 & 5,05 \\
\hline 9 & Молдова & 4,33 & 26 & 5,03 & 4,57 & 2,77 & 4,95 \\
\hline 10 & Україна & 4,29 & 27 & 4,33 & 5,44 & 2,84 & 4,56 \\
\hline 11 & Марокко & 4,23 & 28 & 5,06 & 3,83 & 3,46 & 4,58 \\
\hline 12 & Сгипет & 3,11 & 36 & 3,54 & 3,03 & 2,46 & 3,42 \\
\hline
\end{tabular}

Джерело: складено за даними СБРР [20]

\section{Алгоритм проведення оцінювання ІК щодо структурного підходу}

1. Визначення структурних компонентів IК.

2. Моніторинг методів та методики оцінювання ІК.

3. Визначення найбільш ефективної методики для проведення дослідження.

4. Визначення еталонних показників глобальних рейтингів, індексів, які характеризують складові частини IК.

5. Визначення вагомості значення структурних компонентів IК для інноваційно-інтелектуального розвитку країни.

6. Оцінювання наявності ІК в країні та чинників, які впливають на його формування та розвиток.

7. Порівняльний аналіз з іншими країнами.

Рисунок 2 - Алгоритм проведення оцінювання інтелектуального капіталу національної економіки за структурного підходу

3 вищенаведених досліджень визначимо алгоритм оцінювання інтелектуального капіталу національної економіки за структурного підходу за методикою SC.

Висновки. Інтелектуальний капітал національної економіки має трирівневу структуру, яка включає людський, організаційний та соціальний капітал.
Однією 3 найбільш ефективних методик оцінювання інтелектуального капіталу національної економіки є система збалансованих показників за структурного підходу. Визначення структурних компонентів та методологія оцінювання інтелектуального капіталу на макрорівні є важливими для розвитку економічної політики в будь-якій країні, яка претендує на високе місце у світовій економічній системі та потребує подальшого дослідження.

Згідно $з$ оцінюванням ІК СБРР інституційні перетворення, які відбулися в Україні, не сприяли іiі інноваційноінтелектуальному розвитку. Водночас українці мають достатній науковий потенціал, навички для інновацій, але неефективність комунікаційно-інформаційної інфраструктури та слабо розвинена інноваційна система гальмують інноваційно-інтелектуальний розвиток України.

\section{Список використаних джерел:}

1. Shultz T. Human Capital in the International Encyclopedia of the Social Sciences. N.Y., 1968, vol. 6.

2. Becker G.S. Human Capital: A Theoretical and Empirical Analysis, with Special Reference to Education, Second Edition. National bureau of economic research. New York. 1975. 264 p.

3. Каленюк І. Інтелектуальний капітал: проблеми визначення та структуризації. Науковий вісник Чернігівського державного інституту економіки і управління. 2008. № 1 (1). С. 4-13.

4. Стюарт Т. Интеллектуальный капитал. Новый источник богатства организаций. Москва : Поколения, 2007. 368 с.

5. Брукинг Э. Интеллектуальный капитал и инновационное развитие региона : монография. Владимир, $2014.192 \mathrm{c}$.

6. Бугас В. Особливості інвестування в інтелектуальний капітал. Проблеми економіки організацій та управління підприємствами КНУТД. 2013. URL: https://knutd.edu.ua/publications/pdf/Visnyk/2013-2/132_135.pdf (дата звернення: 23.05.20).

7. Кендюхов О. Інтелектуальний капітал підприємства: методологія формування механізму управління. Донецьк : ДонУЕП, 2006. $307 \mathrm{c}$

8. Edvinsson L., Malone M.S. Intellectual Capital: Realizing Your Company’s True Value by Finding Its Hidden Brainpower. N.Y. : Harper Business, 1997. 240 p.

9. Чухно А. Інтелектуальний капітал: сутність, форми і закономірності розвитку. Економіка Украӥни. 2002. № 12. С. 61-67.

10. Зинов В., Сафарян К. Интеллектуальный капитал как базовая характеристика стоимости бизнеса. Интелектуальная собственность. 2001. № 5-6. С. 23-25.

11. Sveiby K. Methods for Measuring Intangible Assets. URL: https://www.sveiby.com/files/pdf/1537275071_methodsintangibleassets.pdf (accessed: 23 May 2020). 
12. Старик Р. Методичні аспекти оцінки рівня інтелектуального капіталу підприємства. Науковий вісник НЛТУ Украйни. 2010. № 20 (15). C. 233-241.

13. Прокопенко О., Школа В., Щербаченко В. Інтелектуальний капітал як базис національної економічної системи. Вісник Донецького університету економіки та права. 2011. № 2. С. 31-36.

14. Смирнов Е. Методи та моделі вимірювання інтелектуального капіталу підприємств. Экономика предприятий. 2011. № 12. C. 219-224.

15. Ступнікер Г. Інтелектуальний капітал як основа розвитку вітчизняних промислових підприємств. Вісник Харківського соціально-економічного інституту. 2010. № 5. С. 40-43.

16. Река Г. Методи оцінки вартості об'єктів інтелектуальної власності як складових інтелектуального капіталу організації. Науковий вісник НЛТУ Украӥни. 2008. № 18.3. С. 240-246.

17. Каплан Р., Нортон Д. Сбалансированная система показателей. От стратегии к действию. Москва : Олимп-Бизнес, 2017. $320 \mathrm{c}$.

18. Дятлов С., Марьяненко В., Селищева Т. Информационно-сетевая экономика: структура, динамика, регулирование : монография. Москва : ИНФРА-М, 2020. 414 с.

19. Доклад о человеческом развитии 2019. URL: http:/hdr.undp.org/sites/default/files/hdr_2019_ru.pdf (дата звернення: 23.05.20).

20. Introducing the EBRD Knowledge Economy Index 2019. URL: https://www.ebrd.com/news/2019/estonia-slovenia-andlithuania-lead-new-ebrd-knowledge-economy-index.html (дата звернення: 23 Мау 2020).

21. Кармазіна О. Регіональний людський розвиток. Державна служба статистики України. 2018. URL: http://www.ukrstat.gov.ua (дата звернення: 23.05.20).

\section{References:}

1. Shultz T. (1968) Human Capital in the International Encyclopedia of the Social Sciences. - N.Y., vol. 6.

2. Becker G.S. (1975.) Human Capital: A Theoretical and Empirical Analysis, with Special Reference to Education, Second Edition. National bureau of economic research. New York. -264 p.

3. Kalenyuk I. (2008) Intelektualjnyj kapital: problemy vyznachennja ta strukturyzaciji. [Intellectual capital: problems of definition and structuring] Scientific Bulletin of the Chernihiv State Institute of Economics and Management. - № 1 (1), p. 4-13.

4. Styuart T. (2007) Intellektual'nyy kapytal. Novyy istochnik bagatstva organizatsiy [A new source of wealth for organizations]. M. : Generations. $-368 \mathrm{p}$.

5. Bruking E. (2014) Intellektual'nyy kapital i innovatsionnoe razvitie regiona [Intellectual capital and innovative development of the region]. Monografiya. Vladimir. - $192 \mathrm{p}$.

6. Bugas V. (2013) Osoblyvosti investuvannja v intelektualjnyj kapital. [Features of investing in intellectual capital]. Problemy ekonomiky orhanizatsii ta upravlinnia pidpryiemstvamy [Problems of economics of organizations and management of enterprises]. KNUTD. URL: https://knutd.edu.ua/publications/pdf/Visnyk/2013-2/132_135.pdf (accessed: 23 May 2020).

7. Kendyukhov O. (2006) Intelektualjnyj kapital pidpryjemstva: metodologhija formuvannja mekhanizmu upravlinnja [Intellectual capital of the enterprise: methodology of formation of the management mechanism]. NAN of Ukraine. Institute of Industrial Economics. - Donetsk : DonUEP. -307 p.

8. Edvinsson L., Malone M.S (1997) Intellectual Capital: Realizing Your Company’s True Value by Finding Its Hidden Brainpower. N.Y., Harper Business, p. 240.

9. Chukhno A. (2002) Intelektualjnyj kapital:sutnistj, formy i zakonomirnosti rozvytku [Intellectual capital: the essence, forms and patterns of development]. Ekonomika Ukrajiny[Economy of Ukraine]. - № 12, p. 61-67.

10. Zinov V., Safaryan K. (2001) Intellektual'nyy kapital kak bazovaya kharakteristika stoimosti biznesa [Intellectual capital as a basic characteristic of business value]. Intelektual'naya sobstvennost'[Intellectual property]. - № 5-6, p. 23-25.

11. Sveiby K.E. (2010) Methods for Measuring Intangible Assets. URL: https://www.sveiby.com/files/pdf/1537275071_methodsintangibleassets.pdf (accessed: 23 May 2020).

12. Staryk R. (2010) Metodychni aspekty ocinky rivnja intelektualjnogho kapitalu pidpryjemstva[Methodical aspects of assessing the level of intellectual capital of enterprises] Science Newsletter NLTU Ukraine. - № 20 (15), p. 233-241.

13. Prokopenko O., Shkola V., Shherbachenko V. (2011) Intelektualjnyj kapital jak bazys nacionaljnoji ekonomichnoji systemy [The intellectual capital base of the national economic system] Bulletin of Donetsk University of Economics and Law. Bulletin of Donetsk University of Economics and Law. - № 2, p. 31-36.

14. Smirnov E. (2011) Metodi ta modeli vimiryuvannya intelektual'nogo kapitalu pidpriemstv[Methods and models for measuring the intellectual capital of enterprises] Ekonomika predpriyatiy[Economics of enterprises]. - № 12, p. 219-224.

15. Stupniker G. (2010) Intelektual'niy kapital yak osnova rozvitku vitchiznyanikh promislovikh pidpriemstv [Intellectual capital as a basis for the development of domestic industrial enterprises] Bulletin of Kharkiv. social economy. in-tu. - № 5, p. 40-43.

16. Reka Gh. (2008) Metody ocinky vartosti ob'jektiv intelektualjnoji vlasnosti jak skladovykh intelektualjnogho kapital orghanizaciji [Methods of estimating the value of intellectual property as components of the intellectual capital of the organization] Scientific Bulletin of NLTU of Ukraine. - № 18.3, p. 240-246.

17. Kaplan R., Norton D. (2017) Sbalansirovannaya sistema pokazateley. Ot strategii k deystviyu [Balanced scorecard. From strategy to action]. - M. : Olympus-Business. $-320 \mathrm{p}$.

18. Dyatlov S., Mar'yanenko V., Selishcheva T. (2020) Informatsionno-setevaya ekonomika: struktura, dinamika, regulirovanie [Information and network economy: structure, dynamics, regulation] monograph. - Moscow : INFRA-M. $-414 \mathrm{p}$.

19. Pedro Conceisao (2019) Doklad o chelovecheskom razvytyy [Human Development Report]. URL: http://hdr.undp.org/sites/ default/files/hdr_2019_ru.pdf(accessed: 23 May 2020).

20. Introducing the EBRD Knowledge Economy Index (2019). URL: https://www.ebrd.com/news/2019/estonia-slovenia-andlithuania-lead-new-ebrd-knowledge-economy-index.html (accessed: 23 May 2020).

21. Karmazin O. (2018) Regional'ny'j lyuds'ky'j rozvy'tok [Regional human development] State Statistics Service of Ukraine. URL: http://www.ukrstat.gov.ua (accessed: 23 May 2020). 
Maksymenko Zhanna

National Aviation University

\section{STRUCTURAL APPROACH METHODS OF ESTIMATING THE INTELLECTUAL CAPITAL OF THE NATIONAL ECONOMY}

During the economic crisis, the global scientific community faces many issues, including: the problems of innovative and intellectual development of the national economy. Research of structural components, formation, development and estimation of the national intellectual capital acquire special urgency. Differentiation of scientific views encourages the search for better methods of assessing the intellectual capital of the national economy. The purpose of the article is to determine in accordance with the structural approach of the methodology for assessing the intellectual capital of the national economy. Methods of information-logical analysis, system-structural and functional analysis were used during the research. The article considers the paradigm of intellectual capital valuation. The epistemology of intellectual capital is studied. The research approaches of scientists to the structural components of intellectual capital are systematized. The system of indicators of the structural approach for an estimation of intellectual capital is substantiated. Methods of balanced indicators, methods of estimation of intellectual capital on the basis of indices are considered. The structural components and methodology of intellectual capital assessment at the state level are generalized. The formation of intellectual capital at different levels of human development is considered. The factors influencing the formation of structural components of intellectual capital and their development are identified. The tasks of the state for human development are defined. The readiness of the national economy on the basis of the Index of Knowledge Economy to the innovative model of development is investigated. Factors that inhibit the innovative development of the country are identified. The use of indicators to assess the level of knowledge development is justified. The importance of the main structural components of the program "Knowledge for Development" is substantiated. The practical value of the results of the article is to determine the algorithm of the SC methodology for the assessment of national intellectual capital in relation to the structural approach.

Key words: intellectual capital, human capital, organizational capital, social capital, evaluation methods.

JEL classification: $\mathrm{C} 18, \mathrm{D} 83, \mathrm{C} 43$ 